\title{
A DESCRIPTIVE ANALYSIS ON CYBER CRIMES: TYPES \& PREVENTIONS IN FINANCIAL TRANSACTIONS
}

\section{AFREEN SULTHANA \& N. SUBRAMANYAM}

Research Scholar, Department of Management Studies, KL Business School, KL University (Deemed to be University), Green Fields, Vaddeswaram, Guntur, Andhra Pradesh, India

Professor (finance), Department of Management, KL University, Vaddeswaram, Vijayawada, Andhrapradesh, India

ABSTRACT
In today's volatile economic environment, the chance and incentive to commit frauds have both increased. Instances of
asset misappropriation, concealment, cybercrime, and accounting fraud are only increasing by the day. With changes in
technology, frauds have taken the form and modalities of gangland, deploying increasingly sophisticated methods of
perpetration. As financial transactions turn into more and more technology-driven, they appear to have become the
weapon of choice when it comes to fraudsters. Information, intelligence, and knowledge are requisite in corporation to
notice and prevent white-collar crime. The call for expansion has given this unit immense opportunities and as a result,
the proliferation in online transactions mounting on technologies like NEFT (National Electronic Fund Transfer), RTGS
(Real-Time Gross-Settlements), ECS (Electronic Clearing Service) and mobile transactions are a glimpse of the deep-
rooted technology in banking and financial matters. But like two sides to a coin, opportunities come with threats and
success comes with its equivalent challenges Thus with the swift expansion of computers, and internet technology, new
forms of worldwide crimes known as 'Cybercrime's has evolved in the scene. In struggle cyber-crime, financial
institutions should assure that their staff and clients are frequently conversant about the risks, such as phishing attacks
and social engineering
KEYWORDS: Cyber-Crime, Financial Fraud, Fraud Detection, Information Management, Knowledge Management.

Received: Jun 01, 2020; Accepted: Jun 20, 2020; Published: Jul 10, 2020; Paper Id.: IJMPERDJUN2020279

\section{INTRODUCTION}

Lately computer and internet becomes quite common and necessary for our lifestyle. Back in 1990, fewer than 1, 00,000 people were able to access Internet worldwide. Now around 2,405,518,376 people are attached to surf internet round the globe. The present time of fast computing brings a replacement world referred to as cyber world. The increasing use of data technology facilitate folk to urge information, store information, share information, etc. The cyber world is a web world where users have tons of data technology mechanisms to try to personal activity as easily and freely as they will transact them in the physical world. In the globalized and liberalized business environment of the previous couple of years, we face a drastically increased volume of frauds, especially within the financial sectors in India. The Indian financial services sectors have witnessed exponential growth in the last decade a growth that has not been without its pitfalls, as incidents of fraud have also been on the rise. Fraud leads to significant losses to the general public exchequer, thus adversely affecting service delivery. The financial fraud is big business, contributing to an it is estimated that 20 billion USD in direct losses annually. Industry experts suspect that this figure is really much higher, as firms cannot accurately identify and measure losses thanks to fraud. The worst effect of monetary frauds is on FDI inflows into India. The time has appeared for financial services 
organizations to follow a more strategic approach to fraud management within. To conquer this challenge, they need stringent and focused steps. There needs to be precision at all levels in organizations to diminish frauds.

\section{Digital India Dream}

- The Digital India programme may be a transformed version of the already running National E-governance Plan.

- The project aims to supply thrust to nine pillars identified as growth areas.

- These pillar clinch broadband highways, cooperatively mobile connectivity, Public Internet Access Programme, eGovernance, e-kranti (which aims to provide electronic delivery of services), Information for all, electronics mechanized, IT for jobs and untimely on yield programs.

\section{What is Cyber Crime?}

As the use of the Internet is mounting, a new face of crime is dissemination rapidly from in-person crime to nameless and faceless crimes linking computers. Cyber crime includes all unauthorized accesses of information and break security like privacy, password, etc. with the use of the Internet. Cyber crimes also includes criminal activities performed by the consumption of computers like virus attacks, financial crimes, sale of illegal articles, pornography, online gambling, e-mail spamming, cyber phishing, cyber stalking, unauthorized access to computer system, theft of knowledge contained within the electronic form, e-mail bombing, physically damaging the pc system, etc cyber crime was broken into two categories and defined as:

- Cyber Crime during a Narrow Sense (computer crime): Any illegal behaviour directed by means of electronic operations that focus on the safety of computer systems, and therefore the data processed by them.

- Cyber Crime for the Period of a Broader Sense (computer-related crime): Any illegitimate behaviour loyal by means of, or in reference to, a computing system or network, together with such crimes as illegal ownership and offering or distributing information by way of a computing system or network.

- $\mathbf{1 8 2 0}$ - Foremost recorded cybercrime

- 1978 - The initial spam e-mail

- 1982 - The first virus was installed on an Apple computer.

\section{Financial Crime}

A primary effect of cybercrime is financial; cybercrime can include many different types of profit-driven criminal activity, including ransom ware attacks, email and internet fraud, and identity fraud, as well as attempts to steal financial account, MasterCard or other payment card information.

\section{Objectives}

- To discover the present scenario of cyber crimes in India the subsequent are objectives.

- To analyze the categories of cyber crimes in financial transactions.

- To re-evaluate the tricks/ techniques handled by cyber criminals.

- To review the present scenario of cyber crimes. 
- To offer set of instructions to be followed as a victim of cyber crime.

- To suggest the defensive measures and safety tips to control and obstacle of cyber crimes.

Scope

Cyber criminals may seek to get personal and financial data for fraudulent purposes. Cyber-enabled data theft is therefore an integral a part of any discussion on fraud. Valuable forms of data may include:

- Personal information (names, bank details, and National Insurance numbers);

- Company accounts;

- Client databases; and

- Intellectual property (for example, new company products or innovations). Victims could also be members of the overall public or businesses

\section{Review of Literature}

Razzaq et al. presented a survey paper on cyber security of data and information on the cyberspace [15]. They analyzed that nothing is safe within the present scenario. They stated that the present cyber security techniques aren't quite efficient for all types of attacks and specialise in the necessity for brand spanking new security mechanisms which aren't based on previous cyber attack signatures but can also defend against future attacks.

Sadeghi et al. presented the necessity for more security and privacy within the IOT (Internet of Things) [22]. They stated that, with the discovery of new types of computing devices in the IOT environment, the assault surface has grown to be very sharp and there is a require for latest security mechanisms that can cover this increased cyberspace of IOT.

\section{Research Gap}

After reviewing of so many articles i could analysed that, so many articles and thesis discussed about cyber crimes and its prevention but nowhere indicated specially about financial crimes.

\section{METHODOLOGY USED}

This learning is based on secondary data. To meet the primary objective of the study the class of cyber crimes is analyzed by reviewing numerous literatures and info Technology Act 2000 as well as the net web site of cyber crime to review the tricks and techniques utilized by cyber criminals to hack the banking systems and make the cyber frauds numerous case studies in numerous news channels are referred. To review the standing of cyber crimes, the data is gathered from annual reports of National Crime Record Bureau (NCRB).

\section{Types of Cyber Crimes in Financial Transaction}

- Ponzi-Schemes: Investment schemes that assure to forfeit moderately high rates of profits for fixed period investments. They are fraudulent investment plans - money isn't invested in the least Instead, every new investment is employed to pay off earlier investors.

- Pyramid Schemes: Schemes which promise consumers or investors large profits based totally on recruiting others to hitch their program, not supported profits from any real investment or real sale of goods to the public. 
Some schemes may hold up to sell a product, but they frequently use the merchandise to cover their pyramid structure.

- Identity Fraud: Somebody impersonate you and uses your personal information to pilfer money.

- Identity Fraud is Common on Internet: Fraudsters give directions to banks for falsified money transfer.

\section{Phishing}

Internet Banking clients receive e-mails which are tricky asking them to give account login, password \& personal details to website which look like their legitimate bank. This information is exploited to steal money from your bank account

\section{Card Fraud}

- Starts with the theft of your bank card.

- Stolen /loss cards remain serviceable.

Thief makes unauthorized purchases with the card until you notify your bank

- Skimming: This involves stealing information off a master card during a legitimate transaction. Fraudsters' swipe the cardboard through an device referred to as a "wedge" or "skimming device" which records all information contained on the magnetic strip. Fraudsters use the stolen information for online purchase or to breed the cardboard.

- Counterfeit Cards: The fraudsters steal cards' information to form fake cards or sell the cardboard information. The wounded infrequently knows as he still has the genuine card in his possession.

- Advance Fee Scams: These scams are usually perpetrated through a letter, email or call offering you an outsized sum of cash if you'll help someone transfer many rupees or other currency out of his country. To initiate the transaction, you're asked to send details of your checking account and an administration fee.

- Fund Transfer Scams: You are asked through a billboard or email to receive a payment into your checking account, and to send it abroad reciprocally for receiving a commission. In so doing, you'll become a celebration to an offence.

- Fake Prizes: A perpetrator claims that you simply have won a non-existent prize. You are asked to send a cheque to pay the taxes or your master card details, or your account number to buy shipping and handling charges to send you the non-existent prize.

\section{INHERITANCE SCAMS}

You get a mail from an 'estate locator' or 'research specialist' purport an unclaimed inheritance or repayment. You are lured into sending a fee to receive information about the way to obtain the purported asset.

- International Lottery Fraud: To show good faith, the perpetrator may send you a cheque which you are instructed to deposit in your account and send the money back to the lottery committee. The perpetrator will create a "sense of urgency," compelling you to send the money before the cheque, which is counterfeit, is returned. 
- Wills and Legacies: A letter or email is shipped to you claiming that an important person has died and had mentioned your name in his will. Usually the scammer will claim to be the deceased's legal advisor and should claim an advance fee

- Identity Theft: Fraudsters are devising new ways to exploit loopholes in technology systems and processes. In case of frauds concerning lesser amounts, they take up hostile software programs or malware attacks, phishing, SMS phishing and whaling (phishing targeting high net worth individuals) apart from stealing confidential data. In February 2013, the RBI advice banks to pioneer certain minimum checks and balances such as the introduction of two factor validation in case of 'card not present' transactions. Unauthorised emails asking for account information for updating bank records are sent by fraudsters.

\section{INTERNET BANKING AND RELATED FRAUDS}

Around $65 \%$ of the whole scam cases reported by banks were technology-related frauds (covering frauds committed through/at an internet banking path, ATMs and other payment channels like credit/debit/prepaid cards), whereas advancerelated fraud accounted for a major proportion (64\%) of the total amount involved in fraud.19Some examples:

- Triangulation/Site Cloning: consumers enter their card details on fraudulent shopping sites. Then these details are misused.

- Hacking: Hackers/fraudsters obtain unauthorised access to the card management platform of banking system. Counterfeit cards are then issued for the purpose of money laundering.

- Online Fraud: Card information is stolen at the time of an online transaction. Fraudsters then use the card information to make online purchases or assume an individual's identity.

- Lost/Stolen Card: It refers to the use of a card lost by a legitimate account holder for unauthorised/illegal purposes.

- $\quad$ ATM Fraud: A fraudster acquires a customer's card and/or PIN and withdraws money from the machine.

- Dumpster Diving: Employees who aren't careful when throwing away papers containing sensitive information may make secret data available to those who check the company's trash.

- False Pretences: Someone with the internet to steal corporate information can get a job with a cleaning company or other vendor specifically to gain legitimate access to the office building.

- Computer Viruses: With every click on the internet, a company's systems are open to the risk of being infected with nefarious software that is set up to harvest information from the company servers.

\section{Modern Banking}

Presently, 74\% of the Indian residents have mobile phones. Mobile payment volumes have hence registered a gentle rise. A latest study on e-commerce in India by Accel Partners sketchy that shopping through mobile phones grow by $800 \%$ in 2013. It is expected to point out a compound annual rate of growth of $150 \%$ by 2016. 


\section{Branchless Banking: An Upcoming Trend}

Connectivity is the spine of digital banking. The high capacity of ICT transactions through banking correspondents has stimulated the institutions to develop an answer that mixes a mobile and a card reader to role together as a micro ATM. This resolution transfers data using USSD technology that doesn't require a sensible phone or internet connection and is thus accessible by a bigger population. A banking correspondent (intermediary) can use this device to deposit or take out money for a customer in rural areas where banking facilities are scarce, thus integrating these regions into core banking systems.

\section{Best Practices for Prevention of Cyber Crime}

Below mentioned security pointers and smart practices could also be followed to reduce the protection risk of Cyber crime:

- By Change the Computer: To avoid cyber attacks, frequently update software system of computers and antivirus. Whereas keeping pc up to now won't shield user from all attacks, it makes it far more tough for hackers to access system, blocks several basic and automatic

- By Selecting Robust Passwords: Passwords area unit on-line identity over web invariably choose a positive identification that have a minimum of eight characters and use a mix of letters, numbers, and symbols (e.g. avoid mistreatment straightforward positive identification like name, town name etc .keep positive identifications in safe place and not use same password for each on-line service. amendment passwords on a daily basis, a minimum of each ninety days.

- By Protective PC with Security Software Package: Security software unremarkably includes firewall and antivirus programs. A firewall controls World Health Organization and what will communicate with pc on-line. Antivirus software package monitors all on-line activities and protects pc from viruses, worms, Trojan horses, and different forms of malicious programs. Antivirus and antispyware software package ought to be organized to update itself, and it ought to do thus when hook up with the web.

- Shield Personal Information: To require advantage of the many on-line services, users can need to offer personal info so as to handle charge and shipping of purchased product. The subsequent list contains some recommendation for a way to share personal info safely online- Phishing messages can usually tell that to act quickly to stay account open, update does not reply to email messages that provoke personal info. True firms won't use email messages to provoke personal info. - once visiting a web site, kind the computer address directly into the net browser instead of follow a link among Associate in Nursing email or instant message.

- Online Offers that Look too Smart to be True Sometimes are: The free software package or service asked for could are bundled with advertising stuff that tracks behaviour and

- Review Bank and Master Card Statements Regularly: The impact of fraud and on-line crimes are often greatly reduced if user will catch it shortly once their knowledge is purloined or now, several banks and services use fraud bar systems that decision out uncommon getting behaviour.

- Be Social-Media Savvy: Make certain social networking profiles (e.g. Face book, Twitter, etc.) area unit set to non-public. 
- Secure Mobile Devices: Bear in mind that mobile device is susceptible to viruses and hackers.

- Secure Wireless Network: Wi-Fi (wireless) networks reception area unit susceptible to intrusion if they're not properly secured.

- Protect Your Data: Make use of encryption for your majority sensitive files such as health records, tax returns, and financial records.

- Guard your e-Identity: Be vigilant when giving out individual information such as your name, address, phone number, or financial information on the Internet.

\section{CONCLUSIONS}

At present criminals have modified their methodology and have started mistreatment advanced technology. so as to take care of them the society, the legal and enforcement authorities will need to amendment. All The offences like social media, master card fraud, phishing, and virus, Malware, Denial of services, Gambling, Hacktivist, Personal knowledge breach, company knowledge breach and virtual currency square measure repeatedly Involvement of male gender for committing cyber crimes is a lot of in age teams 18-30 compare to feminine cyber crime relies on lack of awareness. This can be a requirement of presidency, medium to coach unguarded persons concerning the damaging areas of the cyber-world as a result of bar is best than cure. Cyber area Security Management has already become a vital element of National Security Management, Military Security Management, Scientific Security Management and Intelligence Management everywhere the globe. Nevertheless Asian country has taken loads of steps to prevent cyber crime however the cyber law cannot afford to be static; it's to vary with the dynamical time.

\section{BIBLIOGRAPHY}

1. GAP (2017) Cyber-Crimes and Prevention. Office of Financial Research, 2017, "Cyber Security and Financial Stability: Risks and Resilience", OFR Viewpoint, February.

2. Information technology act 2000.

3. Newspapers books and magazines.

4. Romano sky, S., 2016, "Examining the costs and causes of cyber incidents", Journal of Cyber security, Vol. 2 (2).

5. Chauhan, Megha. "When Virtual World Meets The Real World: Cyber Crime Induced Drug Trafficking." IMPACT: International Journal of Research in Humanities, Arts and Literature (IMPACT: IJRHAL) 2.2 (2014):115-126.

6. Ali, Sadaqat. "An Empirical Analysis of Knowledge Management of White Color Workers in Public Sector Companies: A Case Study of Bhilai Steel Plant." IMPACT: International Journal of Research in Business Management (IMPACT: IJRBM) 2.8 (2014):1-18. 

